\title{
Power Recovery Support Tabunio Watershed Based on Analysis of Erosion Based on Geographic Information System in the Province of South Kalimantan
}

\author{
Syarifuddin Kadir ${ }^{1}$ \\ Badaruddin ${ }^{1}$ \\ Nurlina $^{2}$ \\ Eka Farma ${ }^{1}$ \\ ${ }^{1}$ Faculty of Forestry, University of Lambung Mangkurat, \\ Banjarbaru 70714, South Kalimantan, Indonesia \\ ${ }^{2}$ Faculty of Mathematics and Natural Sciences, University of Lambung Mangkurat, \\ Banjarbaru 70714, South Kalimantan, Indonesia
}

Doi: $10.2478 / \mathrm{mjss}-2018-0075$

\section{Abstract}

\begin{abstract}
Watershed Tabunio is one of the watershed in the Province of South Kalimantan which has an important role to support the environmental aspects and socio-economic aspects, it is caused by the upstream part of the watershed there are different types of land use can increase the rate of erosion, the flow surface, also on the middle and downstream utilized by the Tanah Laut for agriculture, plantation and fisheries. This study aims to determine the level of erosion, which is useful as a reference for determining the direction of land use for the carrying capacity of watershed restoration efforts Tabunio. This research method using a regional approach ecological watershed analysis process and presentation done spatially through Geographic Information Systems. The results showed that: a) Amount highest erosion 219,08 ton/ha/yr on Land Unit 3B (mining land use with a gradient of 3-8\%), while the lowest amount of erosion 11,44 ton/ha/yr on Land Unit 8 (use secondary dry forest with gradients of 25-40\%); b) The level of erosion is very light Danger land unit 8 on the use of secondary dry forest on the slope of 25-40\%), while other land units at the rate of moderate to severe erosion. Recovery of the carrying capacity of the watershed Tabunio lower the rate of erosion through soil and water conservation vegetatively and civil engineering (mechanical).
\end{abstract}

Keywords: Erosion, carrying capacity and Geographic Information System

\section{Introduction}

A characteristic of the watershed is a parameter determining the vulnerability of flood prone. Tanah Laut including Watershed Tabunio in the period 2007 to 2010 looks increasingly risen to 22 villages (Agency for Research and Development, 2010). Critical land in the watershed is Tabunio area of 19109.89 ha or $31 \%$ of the watershed (Center for Barito Watershed Management, 2013). The population of the watershed is increasing and requires Tabunio land resources to improve the welfare of society. Damage to the environment has become a concern of many parties, due to the increased perceived natural disasters, such as floods, landslides and drought. Accordingly, necessary to study the level of erosion hazard characteristic part of the watershed is the reference watershed restoration.

Barito Watershed Management (2013), states that that particular watershed SWP Tabunio with 242.442.5 ha area are critical land area of 56.881.6 ha. whereas in 2013 there were critical land area of 66.966 .6 ha, an increase of $17.7 \%$, which cause abnormal discharge fluctuations in the availability of water for domestic use and for agricultural wetlands

This study aims to determine the level of erosion hazard to vote Watershed characteristics 
Tabunio. Benefits of this experiment are expected to be the basis of determining the direction of land use for watershed restoration efforts Tabunio.

\section{Methods}

\subsection{Location Research}

The study was conducted in the watershed Tabunio which is administratively located in the district of Tanah Laut South Kalimantan as shown in Figure 1. The experiment was conducted in 2015 through 2016. Tabunio DAS consists of three sections as shown in Table 1.

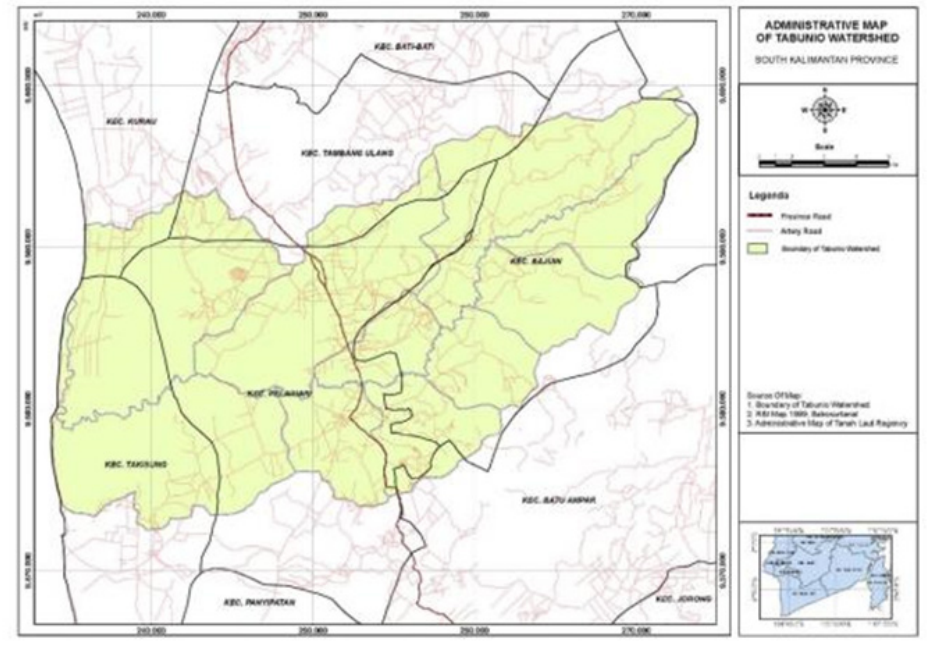

Figure 1. Map of Administrative watershed Tabunio

Table 1. Watershed Tabunio

\begin{tabular}{|l|l|l|l|c|}
\hline No & $\begin{array}{l}\text { Watershed part } \\
\text { Tabunio }\end{array}$ & Subzone & Village & $\begin{array}{c}\text { Large } \\
\text { (ha) }\end{array}$ \\
\hline 1. & Upstream & $\begin{array}{l}\text { 1)Tebing Siring; 2)Amparo } \\
\text { Kecil; 3) Riam }\end{array}$ & Tebing Siring; Tanjung; Sungaibakar; Martadah & $17,542.82$ \\
\hline 2 & Middle & $\begin{array}{l}\text { 1)Berasau; 2)Bakar; } \\
\text { 3)Atu-atu; 4) Kandangan }\end{array}$ & $\begin{array}{l}\text { Pabahanan; Bajuin; Atu-atu; Ketapang; Kunyit; } \\
\text { Angsau; Galam; Tirtajaya; Pamalongan; Pantailinuh; } \\
\text { Tampang; Gunungmelati; Saranghalang }\end{array}$ & $13,038.44$ \\
\hline 3 & Downstream & $\begin{array}{l}\text { Sungaijelai; Ambungan; Panggung; Pelaihari; } \\
\text { Panjaratan; Ujung batu; Panggungbaru; Tugkaran; } \\
\text { Tabanio; Pegatan besar; Guntung besar; Ranggang; } \\
\text { Ranggang dalam; Takisung; Gunung makmur; } \\
\text { Benualawas; Benuatengah; Batilai; Telaga }\end{array}$ & Panjaratan; 2) \\
Tungkaran; 3) Takisung & & \\
\hline
\end{tabular}

\subsection{Tools and Materials Research}

Tools and materials research consists of: a) A set of Computers; b) Software ArcGIS geographic information system; c) Global Position System; d) Digital Cameras; e) Ring Samples; f) Drill Land. A necessary ingredient in this study are: a) Map Tanah Laut regency administration; b) map Tabunio basin; c) Map of soil types, Tanah Laut District; d) The land cover map Tanah Laut; e) Data Digital Elevation Model (DEM) of $30 \times 30 \mathrm{~m}$ pixel Tanah Laut; $\mathrm{f}$ ) Data rainfall and number of days of rain the last 10 years. 


\subsection{Analysis}

This study uses a watershed approach ecological area using Universal Soil Loss Equation (USLE) method, process analysis and presentation done spatially through Geographic Information Systems. The process flow diagram for estimating erosion watershed characteristics Tabunio votes in Tanah Laut is presented in Figure 2 and sub watershed Tabunio in Figure 3.

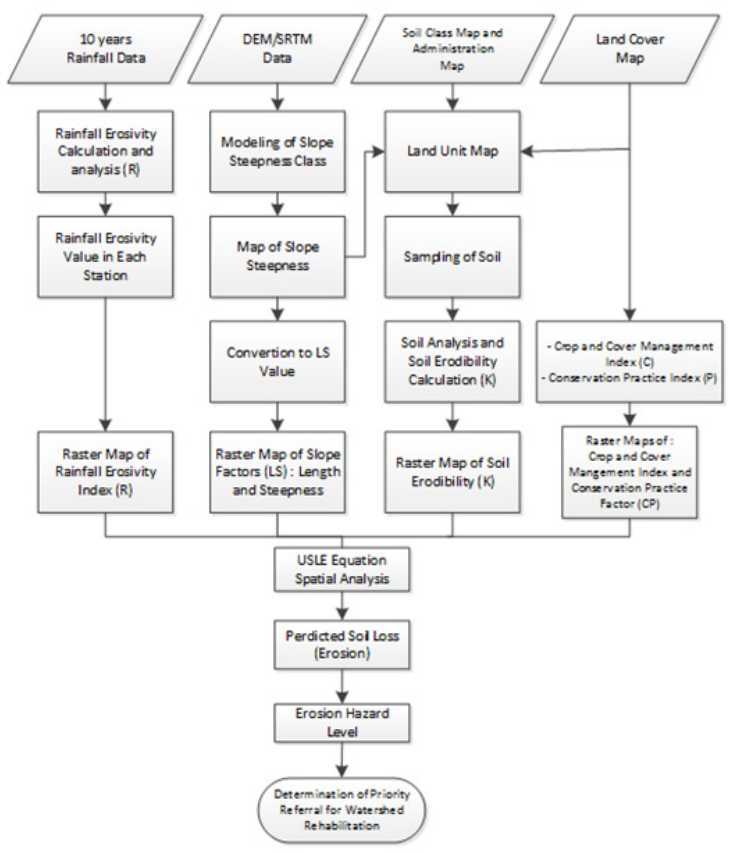

Figure 2. Process Flow Diagram Figure

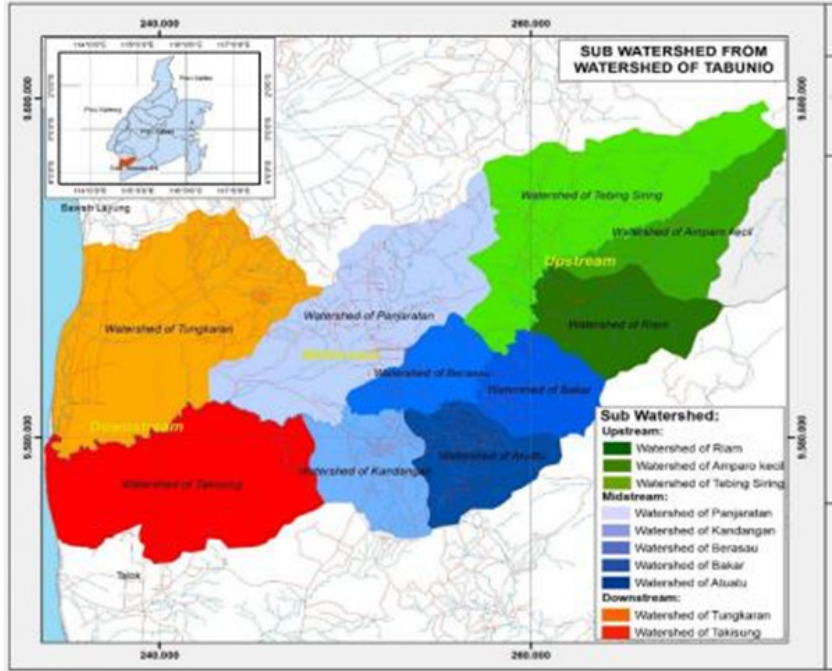

Figure 3. Map Sub watershed Tabunio 


\section{Results and Discussion}

Based on research conducted in the watershed Tabunio, the information obtained watershed characteristics consisting of: a) the land unit: b) the value of erosion; c) Erosion Hazard rate as a factor in watershed characteristics votes.

\subsection{Land unit}

Results overlay unit soil maps, land cover and slope, then acquired the land unit as the unit of analysis. The number of units of land are presented in Table 2. Map of the land unit is presented in Figure 4.

Table 2. Total Land Area Research Unit

\begin{tabular}{|c|c|c|c|c|c|}
\hline No & Land unit & Area $(\mathrm{Ha})$ & Land Cover & Soil Map units & Slope (\%) \\
\hline \multirow{2}{*}{1} & UL 1a & 1.474 & Amalgamated plantations & \multirow{2}{*}{ Dystrudepts } & \multirow{2}{*}{$0-3 \%$} \\
\hline & UL $1 b$ & 3.327 & Shrubs and thickets & & \\
\hline \multirow{2}{*}{2} & UL 2a & 7.215 & Plantation & \multirow{2}{*}{ Endoaquepts (sulfic) } & \multirow{2}{*}{$0-3 \%$} \\
\hline & UL $2 b$ & 4.924 & Shrubs and Thicket Swamp & & \\
\hline \multirow{2}{*}{3} & UL $3 a$ & 6.859 & Plants Mixed & \multirow{2}{*}{ Hapludox } & \multirow{2}{*}{$3-8 \%$} \\
\hline & UL 3b & 2.102 & Mining & & \\
\hline \multirow{2}{*}{4} & UL 4a & 3.509 & Amalgamated plantations & \multirow{2}{*}{ Kandiudults } & \multirow{2}{*}{$3-8 \%$} \\
\hline & UL 4b & 2.407 & Shrubs and thickets & & \\
\hline \multirow{2}{*}{5} & UL 5a & 8.736 & Plantation & \multirow{2}{*}{ Kanhapluduts (skel) } & \multirow{2}{*}{$3-8 \%$} \\
\hline & UL 5b & 3.274 & Plantation & & \\
\hline \multirow{2}{*}{6} & UL 6a & 2.450 & Dryland Mixed Farming & \multirow{2}{*}{ Kanhapluduts } & \multirow{2}{*}{$3-8 \%$} \\
\hline & UL $6 \mathrm{~b}$ & 2.904 & Shrubs and thickets & & \\
\hline \multirow{2}{*}{7} & UL 7a & 2.599 & Plantation & \multirow{2}{*}{ Kandiudox } & \multirow{2}{*}{$8-15 \%$} \\
\hline & UL $7 \mathrm{~b}$ & 5.393 & Shrubs and thickets & & \\
\hline 8 & UL 8 & 5.389 & Dryland Forests Secondary & Inceptisols & $25-40 \%$ \\
\hline
\end{tabular}

Source: The results of primary data in 2015

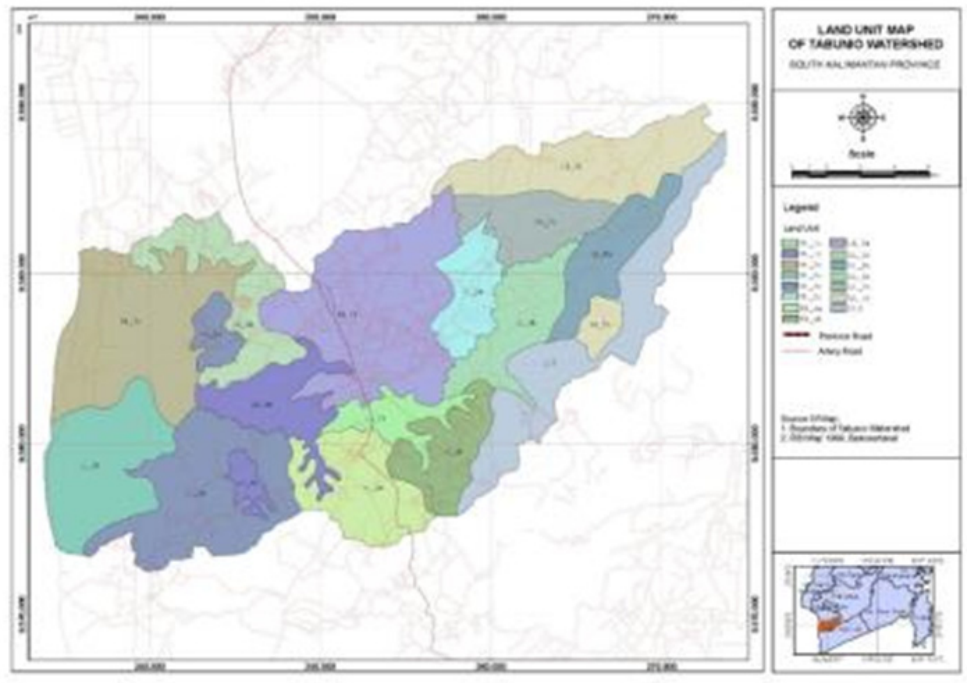

Figure 4. Map of the land unit Watersheds Tabunio 
Table 2 shows that the overlay of the land unit made up of 15 units, then it appears that the largest land unit UL 3a. 6,859 ha on land use mix plants with a slope of $3-8 \%$, while the smallest land units UL 1a. 1,474 ha in plantation land use mix with slopes $0-3 \%$. Land unit is the smallest unit in watershed management, based on the characteristics of the land unit can be a reference or recovery efforts and maintain it.

Zhang et al. (2008) suggested that the unit of land in a watershed is generally regarded as a development unit which rely on the availability of water. Hernandez-Ramirez, (2008) suggested that the planning of land use and management using the watershed as the management unit. Soemarno (2011) unit of land in the watershed can be used as a means of monitoring the land use either as a unified ecosystem.

\subsection{Total Erosion}

Results of analysis for determining the amount of erosion using USLE equation, the obtained amount of erosion per unit of land as presented in Table 3.

Table 3. Total Erosion on each unit of land in the watershed Tabunio

\begin{tabular}{|c|c|c|c|c|c|c|c|c|}
\hline No & Land unit & Area (ha) & $\mathbf{( R )}$ & $\mathbf{( K )}$ & LS & $\mathbf{( C )}$ & $\mathbf{( P )}$ & $\mathbf{A}$ \\
\hline 1 & UL 1A & 1.474 & 1579 & 0,153 & 0,35 & 0,6 & 1 & 50,88 \\
\hline & UL 1B & 3.327 & 1579 & 0,124 & 0,35 & 0,4 & 1 & 27,16 \\
\hline 2 & UL 2A & 7.215 & 1579 & 0,104 & 0,35 & 0,5 & 1 & 28,55 \\
\hline & UL 2B & 4.924 & 1579 & 0,142 & 0,35 & 0,02 & 1 & 1,55 \\
\hline 3 & UL 3A & 6.859 & 1579 & 0,147 & 0,82 & 0,1 & 1 & 19,07 \\
\hline & UL 3B & 2.102 & 1579 & 0,169 & 0,82 & 1 & 1 & 219,08 \\
\hline 4 & UL 4A & 3.509 & 1579 & 0,111 & 0,82 & 0,5 & 1 & 71,49 \\
\hline & UL 4B & 2.407 & 1579 & 0,133 & 1,06 & 0,4 & 1 & 89,11 \\
\hline 5 & UL 5A & 8.736 & 1579 & 0,210 & 0,82 & 0,5 & 1 & 136,11 \\
\hline & UL 5B & 3.274 & 1579 & 0,059 & 1,10 & 0,6 & 1 & 61,93 \\
\hline 6 & UL 6A & 2.450 & 1579 & 0,093 & 1,57 & 0,45 & 0,35 & 36,35 \\
\hline & UL 6B & 2.904 & 1579 & 0,096 & 1,37 & 0,1 & 1 & 20,87 \\
\hline 7 & UL 7A & 2.599 & 1579 & 0,124 & 2,65 & 0,6 & 0,35 & 108,80 \\
\hline & UL 7B & 5.393 & 1579 & 0,093 & 2,65 & 0,5 & 0,6 & 116,34 \\
\hline 8 & UL 8 & 5.389 & 1579 & 0,100 & 14,54 & 0,005 & 1 & 11,44 \\
\hline
\end{tabular}

Description: $A=$ Number of erosion (ton/ha/yr), $R=$ Erosivity Value, $K=$ Erodibility Value, $L S=$ The length and slope, land cover $\mathrm{C}=$ Value, $\mathrm{P}=$ conservation measures Value

Source: The results of primary data in 2015.

In Table 3 shows that the highest amount of erosion 219.08 ton/ha/yr on land unit 3B (mining land use with slopes $3-8 \%$ ), while the lowest value of normal erosion consideration of land cover on land units UL 8 sebesar11,44 ton/ha/yr on dry land forest land use secondary with gradients of $25-40 \%$. Changes in land use into mining activities often reduce infiltration and otherwise improve runoff and erosion, so that the necessary consideration and planning of land use changes. Kadir (2016) and Asdak (2010) land cover affect runoff and erosion.

Steel (2012) stated that in land use planning and the selection of the type of land use, determining the optimal spatial location of the planned activities, should identify and formulate opportunities for land use changes, and anticipate the consequences of land use changes. Zhao et al. (2012) reported that the demolition of land cover in a watershed effect on runoff and soil erosion.

Hernandez-Ramirez (2008) suggested that land use planning, management and ecological restoration are using the watershed as the management unit. Changes in land use have a negative impact on environment.

Asdak (2010), the amount of water that goes into the ground through the infiltration process is influenced by several factors, among others, the texture and structure of soil and land cover, these factors interact to affect infiltration and runoff and erosion. 
Aspects of the slope proved to have a major impact on the rate of soil erosion, and the slopes exposed to the sun appeared to have a greater erosion than the shaded slopes, especially for agricultural land (Li et al., 2010).

\subsection{Erosion Hazard Level}

Arsyad (2010), the movement of soil erosion is an event or portions of land from one place to another by natural media. Furthermore, according to Yu (2003), the low capacity of infiltration causes heavy erosion as a result of high runoff. Based on the value erosion in Table 2, it can be determined the level of erosion per unit of land by considering the depth of solum.

In Table 3 shows that the rate of erosion in the watershed Tabunio consists of; a) 5 land classification unit weight; b) 5 units of land classification being; c) 2 units of land classification of light; and d) 2 unit is very light land classification.

Unit lands with severe erosion hazard level classification is dominated by mining land cover, shrubs and plantations solum into the mixture at $60-90 \mathrm{~cm}$. Erosion hazard level classification is determined by the physical properties of the soil and its closure and soil solum. Is shown in Table 3 that land mines (UL3B) including severe erosion hazard level classification it is because of the high sensitivity of soil eroded fatherly (UL3B in Table 3). According Arsyad (2010), soil properties that affect sensitivity to erosion.

Sajikumar and Remya (2015) evaluated the effects of land use and land cover on runoffsurface characteristics of the two watersheds in Kerala, India. Furthermore Zhang, et al. (2015), the land of former opencast coal mine in Shanxi province may increase the rate of erosion.

Mainuri and Owino (2014) study the relationship between landscape and land use, soil degradation. Solum is one of the characteristics of the soil in a watershed that could affect the infiltration, runoff and erosion. Kadir et al. (2013) reported that the rehabilitation of mined lands through vegetative and mechanical is one of the best alternatives to control the level of vulnerability to flooding and erosion. Cao et al. (2015) reported that a potential erosion and runoff showed a significant increase. Map of erosion hazard level is presented in Figure 5. Value Erosion Hazard Level for each unit of land in Table 4.

Table 4. Value Erosion Hazard Level for each unit of land in the watershed Tabunio

\begin{tabular}{|c|c|c|c|c|c|c|c|}
\hline \multirow{2}{*}{ No } & \multirow{2}{*}{ Land unit } & \multirow{2}{*}{ Area (ha) } & \multicolumn{2}{|c|}{ Depth } & \multicolumn{2}{c|}{ Erosion hazard } & \multirow{2}{*}{ Erosion Hazard Level } \\
\cline { 4 - 7 } & & & $\mathbf{( c m})$ & Class & ton/ha/yr & Class & \\
\hline 1 & UL 1A & 1.474 & $>90$ & Deep & 50,88 & II & Light \\
\hline & UL 1B & 3.327 & $60-90$ & Moderate & 27,16 & II & Moderate \\
\hline 2 & UL 2A & 7.215 & $>90$ & Deep & 28,55 & II & Light \\
\hline & UL 2B & 4.924 & $>90$ & Deep & 1,55 & I & Very light \\
\hline 3 & UL 3A & 6.859 & $>90$ & Deep & 19,07 & II & Light \\
\hline & UL 3B & 2.102 & $>90$ & Deep & 219,08 & IV & Heavy \\
\hline 4 & UL 4A & 3.509 & $60-90$ & Moderate & 71,49 & III & Heavy \\
\hline & UL 4B & 2.407 & $60-90$ & Moderate & 89,11 & III & Heavy \\
\hline 5 & UL 5A & 8.736 & $60-90$ & Moderate & 136,11 & III & Heavy \\
\hline & UL 5B & 3.274 & $60-90$ & Moderate & 61,93 & III & Heavy \\
\hline 6 & UL 6A & 2.450 & $60-90$ & Moderate & 36,35 & II & Moderate \\
\hline & UL 6B & 2.904 & $60-90$ & Moderate & 20,87 & II & Moderate \\
\hline 7 & UL 7A & 2.599 & $>90$ & Deep & 108,80 & III & Moderate \\
\hline & UL 7B & 5.393 & $>90$ & Deep & 116,34 & III & Moderate \\
\hline 8 & UL 8 & 5.389 & $>90$ & Deep & 11,44 & I & Very light \\
\hline
\end{tabular}

Source: The results of primary data in 2015. 


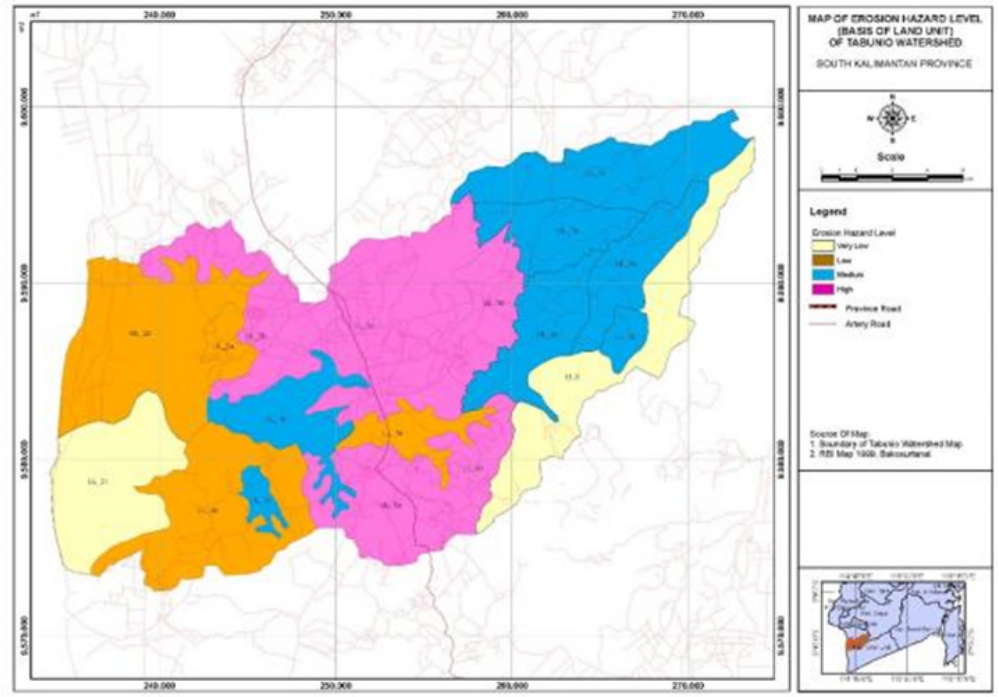

Figure 5. Map of the erosion hazard level watershed Tabunio

Differences in soil depth and soil permeability, together with differences in vegetation cover, can determine differences in surface runoff processes that occur at each location, and Explains the differences in the characteristics of hydrograph (Lana-Renault, et al., 2011). Furthermore Kadir et al. (2016), the enrichment of vegetation types based on the suitability of land in the watershed Tabunio is one of a watershed restoration efforts.

\subsection{Forest and land rehabilitation referrals}

Recovery of the carrying capacity of the watershed Tabunio lower the rate of erosion through soil and water conservation vegetatively and civil engineering (mechanical). Forest and land rehabilitation in Table 5. Map of the Forest and land rehabilitation is presented in Figure 6.

Tabel 5. Forest and land rehabilitation in watershed Tabunio

\begin{tabular}{|c|c|l|c|l|c|}
\hline No & Land unit & land use & erosion hazard level & Rehabilitation models & Area (ha) \\
\hline 1 & UL 3B & Mining & Heavy & Rehabilitation and terracing & 2.102 \\
\hline 2 & UL 4A & Plantation & Heavy & Terracing & 3.509 \\
\hline 3 & UL 4B & Shrubs and thickets & Heavy & Rehabilitation and Traditional terracing & 2.407 \\
\hline 4 & UL 5A & Plantation & Heavy & Terracing & 8.736 \\
\hline 5 & UL 5B & Dryland Agriculture & Heavy & Traditional terracing & 3.274 \\
\hline \multicolumn{4}{|l|}{ Total } & & 20.028 \\
\hline
\end{tabular}

In Table 5 showed that to lower the rate of erosion unit mining lands and shrubs are expected to do rehabilitation activities and the making terracing, while unit plantation land and dryland agriculture need to manufacture terracing to reduce runoff and improve infiltration.

Barito Watershed Management (2013), states that the critical land in the unit area watershed management Tabunio 2009 to 2013 increased by $17.7 \%$. The rise in critical land in a watershed to be a factor causing increased runoff and erosion hazard level.

Based on the amount of erosion and erosion potential levels obtained in this study became the basis of determining the model forest and land rehabilitation which implies lower levels of erosion. Enrichment vegetation suitable land suitability and the use of terracing can be a model that 
can reduce the level of erosion. Kadir et al. (2016), the enrichment of vegetation types based on the suitability of land in the watershed Tabunio is one of a watershed restoration efforts.

Sriwongsitanon (2011), changes in the type of land use affects water management in a watershed. Land use and types of vegetation affects land capacity on hydrology and soil erosion, but it can change the characteristics of the ground and into alternative forest and land rehabilitation (Nunes, Almeida and Coelho, 2011).

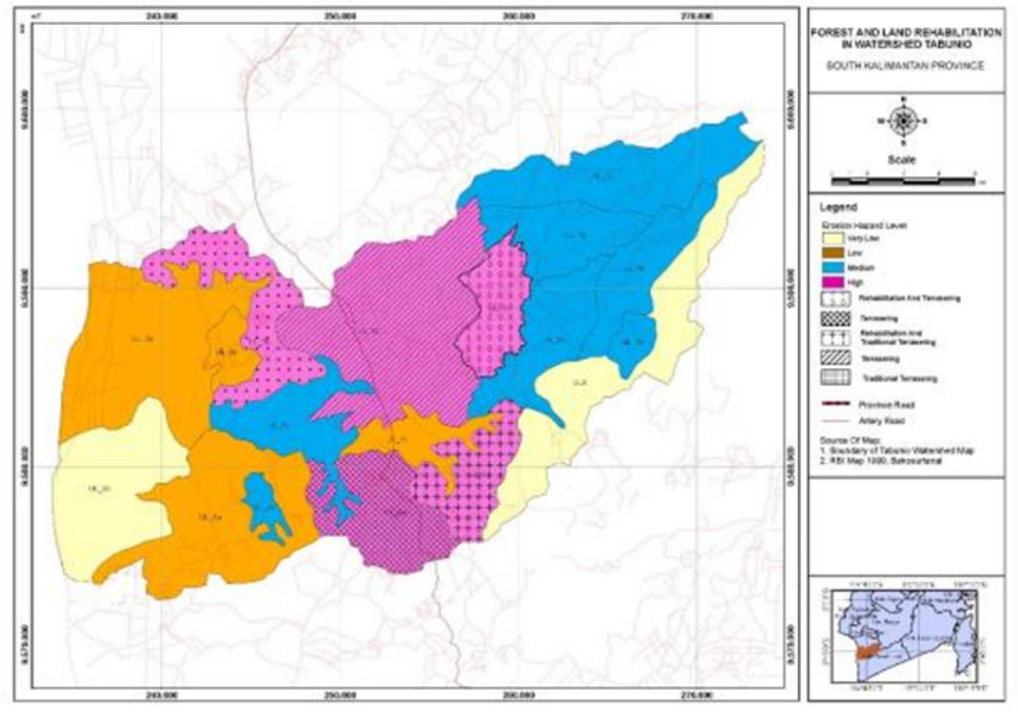

Figure 6. Map of the Forest and land rehabilitation in watershed Tabunio

\section{Conclusions and Recommendations}

Based on the results of research and discussion that has been done, it can be concluded

1. The unit of land overlay of soil type, land cover and slope consisting of 15 units of land (land units $1 \mathrm{~A}-\mathrm{B}, 2 \mathrm{~A}-\mathrm{B}, 3 \mathrm{~A}-\mathrm{B}, 4 \mathrm{~A}-\mathrm{B}, 5 \mathrm{~A}-\mathrm{B}, 6 \mathrm{~A}-\mathrm{B}, 7 \mathrm{~A}-\mathrm{B}$ and unit land 8 ).

2. The amount of the highest erosion $219.08 \mathrm{ton} / \mathrm{ha} / \mathrm{yr}$ on Land Unit 3B (mining land use), while the lowest amount of erosion of 11.44 ton / ha / $\mathrm{yr}$ on land unit 8 (use of dry-land forests secondary.

3. Danger Level severe erosion on land unit $3 B, 4 A, 4 B, 5 A$ and $5 B$, while the rate of erosion mild to moderate land units $1 \mathrm{~A}, 1 \mathrm{~B}, 2 \mathrm{~A}, 2 \mathrm{~B}, 6 \mathrm{~A}, 6 \mathrm{~B}, 7 \mathrm{~A}, 7 \mathrm{~B}$ and 8 .

4. The level of erosion hazard highest Tabunio affect the carrying capacity of watershed land use land mines.

Recovery of the carrying capacity of the watershed Tabunio lower the rate of erosion through soil and water conservation vegetative biophysical functioning as a regulator of water and improve the economic welfare of society, but it is the civil structure to manufacture terracing.

\section{References}

Arsyad, S. 2010. Soil and Water Conservation, the First Edition. IPB Press. Bogor.

Asdak. 2010. Hydrology and Watershed Management. Prints Fifth (revised) Gadjah Mada University Press. Yogyakarta.

Baja,S. 2012. Analytical methods of evaluation of land resources. GIS applications, fuzzy set, dan MCDM, Identity Hasanuddin University, Makassar..

Center for Barito Watershed Management. 2013. Updating of Spatial Data of Degraded Land in the Working Area of the Office of Barito Watershed Management. The Office of Barito Watershed Management, Banjarbaru. [Indonesian] 
Cao,L., Y.Liang, Y.Wang dan H.Lu. 2015. Runoff and soil loss from Pinus massoniana forest in southern China after simulated rainfall. CATENA. 129: 1-8.

Hernandez-Ramirez, G. 2008. Emerging Markets for Ecosystem Services: A Case Study of the Panama Canal Watershed. Journal of Environment Quality. 37

Kadir, S., Rayes, M. L., Ruslan, M., and Kusuma, Z. 2013. Infiltration To Control Flood Vulnerability A Case Study of Rubber Plantation of Dayak Deah Community in Negara, Academic Research International. Natural and Applied Sciences. 4 (5):1-13. http://www.savap.org.pk.

Kadir, S., Badaruddin Nurlina dan Fonny Rianawaty. 2016. The recovery of Tabunio Watershed through enrichment planting using ecologically and economically valuable species in South Kalimantan, Indonesia. Biodiversitas ISSN: 1412-033X Volume 17, Number 1, April 2016

Lana-Renault,N., J. Latron, D. Karssenberg, P. Serrano-Muela, D. Regüés dan M.F.P. Bierkens. 2011. Differences in stream flow in relation to changes in land cover: A comparative study in two subMediterranean mountain catchments. Journal of Hydrology, 411(3-4): 366-378.

Mainuri,Z.G. dan J.O.Owino. 2013. Effects of land use and management on aggregate stability and hydraulic conductivity of soils within River Njoro Watershed in Kenya. International Soil and Water Conservation Research, 1(2): 80-87.

Nunes,A.N., A.C.deAlmeida dan C.O.A.Coelho. 2011. Impacts of land use and cover type on runoff and soil erosion in a marginal area of Portugal. Applied Geography, 31(2): 687-699.

Sajikumar,N. dan R.S. Remya. 2015. Impact of land cover and land use change on runoff characteristics. Journal of Environmental Management, In Press, Corrected Proof, Available online 7 January 2015

Soemarno. 2008. Modeling System in the Management of Natural Resources and Environment. Graduate Program, University of Brawijaya, Malang.

Sriwongsitanon,N. dan W.Taesombat. 2011. Effects of land cover on runoff coefficient. Journal of Hydrology, 410(3-4): 226-238

Research and Development Agency of South Kalimantan Province and the Faculty of Forestry Unlam. Masterplan 2010. Floods and Their Management in South Kalimantan, Banjarmasin.

Yu, J., Lei, T., Shainberg, I., Mamedov, A. I., and Levy, G. J. (2003). Infiltratin and Erosion in Soils Treated With Dry Pam and Gypsum. Soil Science Society of America Journal. 67 (2): 630-636.

Zhang, X., Yu, X., Wu, S., and Cao, W. 2008. Effects of Changes In Land Use and Land Cover on Sediment Discharge of Runoff In A Typical Watershed In the Hill and Gully Loess Region of Northwest China. Frontiers of Forestry in China. 3 (3): 334-341. doi:10.1007/s11461-008-0056-1.

Zhao, Y., Zhang, K., Fu, Y., and Zhang, H. 2012. Examining Land-Use/Land-Cover Change in the Lake Dianchi Watershed of the Yunnan-Guizhou Plateau of Southwest China with remote sensing and GIS techniques: 1974-2008. International Journal of environmental research and public health. 9 (11): 3843-65. doi:10.3390/ijerph9113843. 